\title{
Pelatihan Manajemen e-Learning Student Centre di SMA N I Jasinga Kabupaten Bogor Jawa Barat
}

\author{
Sugianto Arjo ${ }^{1}$ \\ Program studi Pendidikan Fisika, FKIP-UHAMKA \\ Hendrik Seputra ${ }^{2}$ \\ Program studi Pendidikan Fisika, FKIP-UHAMKA \\ Mirzanur Hidayat ${ }^{3}$ \\ Program studi Pendidikan Fisika, FKIP-UHAMKA \\ Tika Kurniawati ${ }^{4}$ \\ Program studi Pendidikan Fisika, FKIP-UHAMKA \\ Badriatusyahria $^{5}$ \\ Program studi Pendidikan Fisika, FKIP-UHAMKA
}

\begin{abstract}
Abstrak
Telah dilakukan pengabdian kepada masyarakat tentang manajemen sistem pembelajaran online atau e-Learning. Sistem pembelajaran e-Learning dibangun berdasarkan pada tingkat kebutuahan di era modern seperti saat ini atau sebagai bentuk perwujudan dari revolusi industri 4.0. Olehkarena itu pelatiahan e-Learning ini selain bertujuan untuk memperkenalkan sistem belajaran modern, juga diharapkan pada pihak sekolah, para guru, staf dan siswa(i) mampu mengoperasikan e-Learning secara mandiri. e-Learning merupakan suatu sistem pembelajaran yang dilakukan secara online sehingga dapa diakses dimanapun dan kapanpun. Metode yang diterapkan pada pelatihan ini yaitu diawali dengan analisis kebutuhan, studi referensi, persiapan, pelaksanaan (workshop) dan elaborasi. Adapun e-Learning yang digunakan dalam pelatihan ini adalah student centre bersifat open dan dapat dijumpai dilaman http://dafturn.org/. student centre ini memuat fitur-fitur informasi mata pelajaran, informasi Board, Resources dan Assignments. Berdasarkan pada hasil analisis kebutuhan di SMAN 1 Jasinga, kabupaten Bogor bahwa penerapan e-Learning di sekolah tersebut belum sama sekali dilaksanakan. Olehkarena itu melalui kegiatan pengabdian masyarakat ini diharapkan semua elemen ditingkat sekolah mampu memahami dan menerapkan sistem tersebut. Hasil pelaksanaan pelatihan manajemen sistem pembelajaran eLearning di SMAN 1 Jasinga memperlihatkan antosiasme yang tinggi dengan hadirnya semua guru dan staf pada kegiatan tersebut. Adapun jumlah peserta yang hadir dalam kegiatan tersebut berjumlah 50 orang. Adapun ketidak hadiran siswa disebabkan oleh padatnya penjadwalan disekolah sehingga tidak memungkinkan pada kegiatan tersebut. Hadirnya guru dan staf pada kegiatan tersebut diharapkan setelah dilakukannya kegiatan ini pihak sekolah dapat menerapkan sistem pembelajaran e-Learning yang sangat fleksibel terhadap situasi penjadwalan.
\end{abstract}

Kata Kunci: e-Learning, student centre, pembelajaran online dan sistem fleksibel 


\begin{abstract}
Community service about the management of online learning systems or e-Learning has been done. The e-Learning learning system is built based on the level of needs in the modern era as it is today or as a manifestation of the industrial revolution 4.0. e-Learning is a learning system that is done online so that it can be accessed wherever and whenever. The e-Learning used in this training is that the student center is open and can be found in the http://dafturn.org. This student center contains features of subject information, Board information, Resources and Assignments. Based on the results of the needs analysis at Jasinga 1 High School, Bogor district that the implementation of e-Learning in the school has not been implemented at all. Therefore, through this community service it is expected that all elements at the school level are able to understand and implement the system. The results of the implementation of the e-Learning management system training at SMAN 1 Jasinga showed high enthusiasm with the presence of all teachers and staff at the activity. The number of participants who attended the activity amounted to 50 people. The absence of students is caused by tight scheduling at school so it is not possible in these activities. The presence of teachers and staff in these activities is expected after this activity the school can implement an e-Learning learning system that is very flexible to the scheduling situation.
\end{abstract}

Keywords: e-Learning, student centre, online learning, fleksible system

1. Latar belakang

Dalam beberapa tahun terakhir, perkembangan teknologi telah banyak merubah kurikulum pembelajaran yang ada di sekolah. Dalam konteks ini penyesuain kurikulum pembelajaran mengikuti perkembangan teknologi termutakhir. eLearning dapat menghilangkan batasan-batasan pembelajaran taradisonal pada lingkup ruang, waktu dan biaya serta menawarkan fleksibilitas bagi siswa maupun guru dalam proses belajar-mengajar. Selain itu, dengan e-Learning kegiatan belajarmengajar akan lebih menarik dan dapat meningkatkan motivasi belajar siswa (Harandi, 2015)

Pengembangan e-Learning ini memuat komponen-komponen perangkat pembelajaran seperti silabus, penugasan, modul/bahan ajar, dan lain sebagainya(Mircea and Associate, 2018).

Dalam rangka meningkatkan mutu pendidikan dan menguranggi batas-batasan dalam proses pembelajaran di SMAN 1 Jasinga Kabupaten Bogor Jawa Barat, kami bermaksud mengadakan pengabdian berupa Pelatihan Pengembangan ELearning di sekolah tersebut. Pelatihan ini dimaksudkan supaya para guru, tenaga akademik dan siswa-siswi di SMAN 1 Jasinga Kabupaten Bogor Jawa Barat dapat menerapan proses pembelajaran dengan sistem elektronik (E-Learning).

\title{
2. Tujuan Kegiatan
}

Tujuan kegiatan ini adalah :

a. Mensosialisasikan e-Learning bagi guru, tenaga kependidikan dan siswa-siswi di SMA I Jasinga Kabupaten Bogor Jawa Barat. 
b. Membimbing Guru, Tenaga Kependidikan serta Siswa-siswi dalam mengaplikasikan e-Learning dalam pembelajaran di SMA N I Jasinga Kabupaten Bogor Jawa Barat.

\section{Manfaat Kegiatan}

Setelah dilaksanakannya kegiatan pengabdian tentang e-Learning ini diharapkan dapat membentuk sistem pembelajaran yang fleksibel tanpa mengurangi alokasi waktu pembelajaran yang telah diterapkan, serta aktivitas guru diluar sekolah pun dapat berjalan sebagaimana mestinya. Bagi para siswa yang berhalangan hadir ke sekolah pun masih dapat mengikuti materi pembelajaran sebagaimana mestinya. Bagi pihak sekolah target penyelesaian pembelajaran di kelas dapat terkontrol secara maksimal (Omwenga, 2017).

\section{Metode}

Dalam kegiatan pengabdian masyarakat yang dilakukan di SMA N 1 Jasinga Kabupaten Bogor Jawa Barat ini didasarkan pada kebutuhan sekolah akan sistem pembelajaran elektronik (e_learning)(Alenezi, 2018). Adapun metodologi pelaksanaan dalam kegiatan pengabdian masyarakat sebagaimana diperlihatkan dalam Gambar 1.

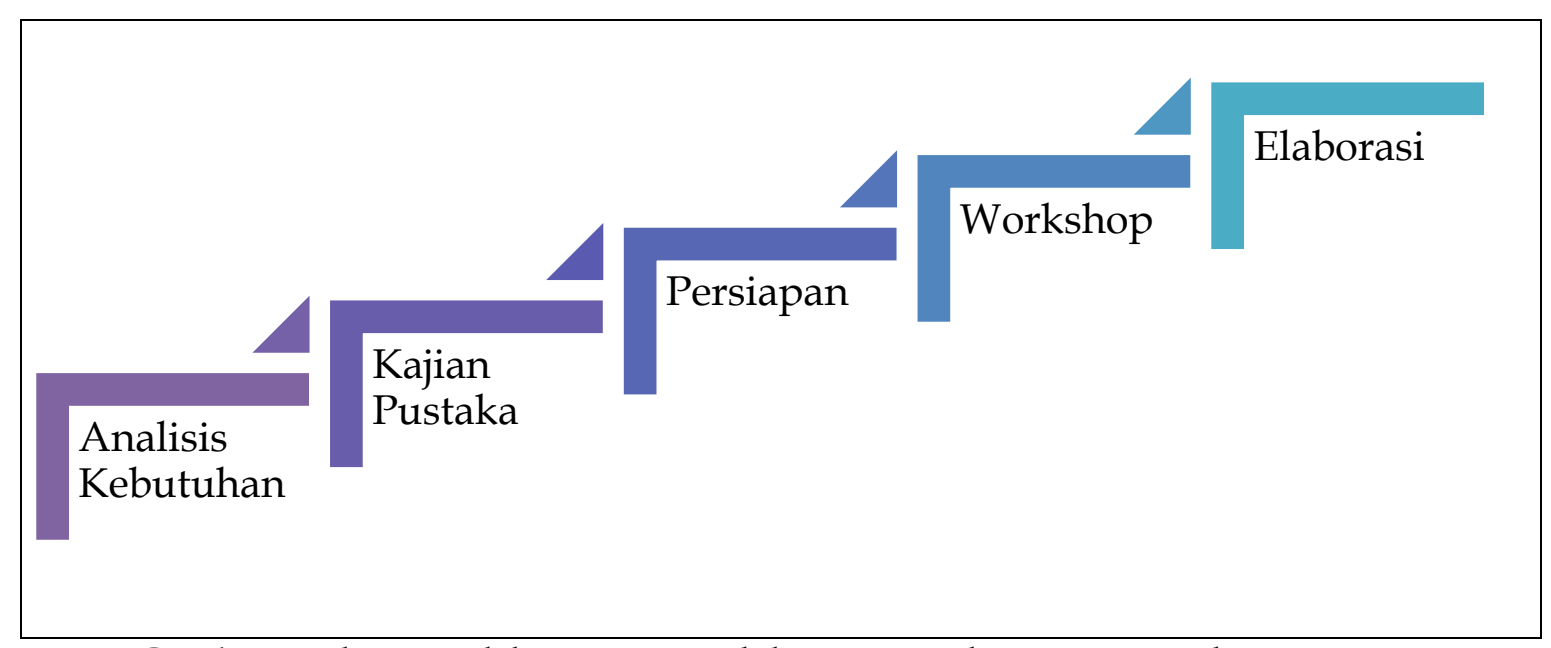

Gambar.1 Tahapan pelaksanaan pengabdian masyarakat secara garis besar

Secara rinci tahapan-tahapan tersebut memuat:

a). Analisis Kebutuhan

Tahapan ini meliputi survey awal ke sekolah, yaitu apakah pembelajaran eLearning telah diterapkan atau sudah sejauh mana tahap pengembangannya, khususnya untuk pelaksanaan ujian setiap semester.

b). Kajian Pustaka

Pada tahapan ini memuat pencarian sumber referensi tentang sistem pembelajaran e-Learning yang telah diterapkan di sekolah-sekolah, khususnya 
referensi yang relevan. Adapaun referensi-referensi yang dijadikan rujukan adalah jurnal-jurnal, atau pelatihan-pelatihan tentang sistem pembelajaran.

\section{c). Persiapan}

Tahap persipan ini meliputi pembuatan modul, menyiapkan perangkat pembelajaran berupa server dan instalansi program e-Learning pada PC yang ada di sekolah tempat kegiatan dilaksanakan.

\section{d). Workshop}

Tahapan ini meliputi pelaksanaan kegiatan yang waktunya telah ditentukan.

\section{e). Elaborasi}

Tahapan elaborasi mencakup kesepakatan untuk kerjasama setelah dilakukannya kegiatan ini. Pihak dari universitas bersedia untuk melakukan pendampingan selama sistem e-Learning ini diterapkan di sekolah.

\section{Hasil dan Pembahasan}

Kegiatan pengabdian kepada masyarakat e-Learning (student centre) di SMA N 1 Jasinga, telah dilaksanakan selama dua hari secara berturut-turut yakni dimulai pada tanggal 22 dan 23 Nopember 2019. Rangkaian seluruh kegiatan diikuti oleh seluruh guru-guru di SMA N 1 Jasinga berjumlah 50 orang. Adapun rangkaian kegiatan yang dilaksanakan selama dua hari tersebut meliputi, instalansi program e-Learning, pengenalan sistem e-Learning dan wokshop e-Learning.

\section{a. Instalasi program e-Learning}

Instalasi program e-Learning dilakukan dalam rangka untuk memenuhi kebutuhan fasilitas pelaksanaan program. Instalasi ini dilakukan di laboratorium komputer SMAN 1 Jasinga untuk penggunaan dan pemanfaatan dalam jangka panjang oleh pihak sekolah. Dimana instalasi tersebut telah mendapatkan persetujuan sebelumnya oleh pihak sekolah dalam hal ini adalah kepala sekolah yang dibuktikan dengan adanya surat pernyataan. Dalam surat pernyataan tertuang adanya menerapkan IPTEK dengan tujuan mengembangkan produk/jasa atau target sosial lainnya seperti penerapan e-Learning untuk sistem pembelajaran (Jati, 2013).

Instalasi program e-Learning dari tim program studi pendidikan Fisika ini merupakan bentuk free dan open source bukan untuk kegiatan yang bersifat komersil, sehingga dapat digunakan oleh pihak manapun, dan di izinkan untuk melakukan modifikasi.

b. Pengenalan Sistem e-Learning

Kegiatan pelatihan e-Learning selajutnya adalah pengelan tentang e-Learning yang diawali dengan kegiatan pembukaan secara langsung diwakili oleh wakil kepala sekolah bidang kurikulum (Wakasek Kurikulum) sekaligus membuka 
kegiatan tersebut. Dalam sesi ini Wakasek Kurikulum menyampaikan tentang maksud dan tunjuan dari kegiatan tersebut sehingga seluruh peserta dapat mengikutinya dengan baik. Dalam hal ini juga pihak sekolah menyampaikan terkait tindak lanjut setelah dilaksanakannya kegiatan ini. Terkait dengan acara sesi pembukaan ini secara visual dapat dilihat dalam Gambar.2.

Sebagai bentuk kelanjutan dari kegiatan ini pihak sekolah akan melakukan komunikasi secaran intensip dengan pihak narasumber untuk pengembangan lebih lanjut.

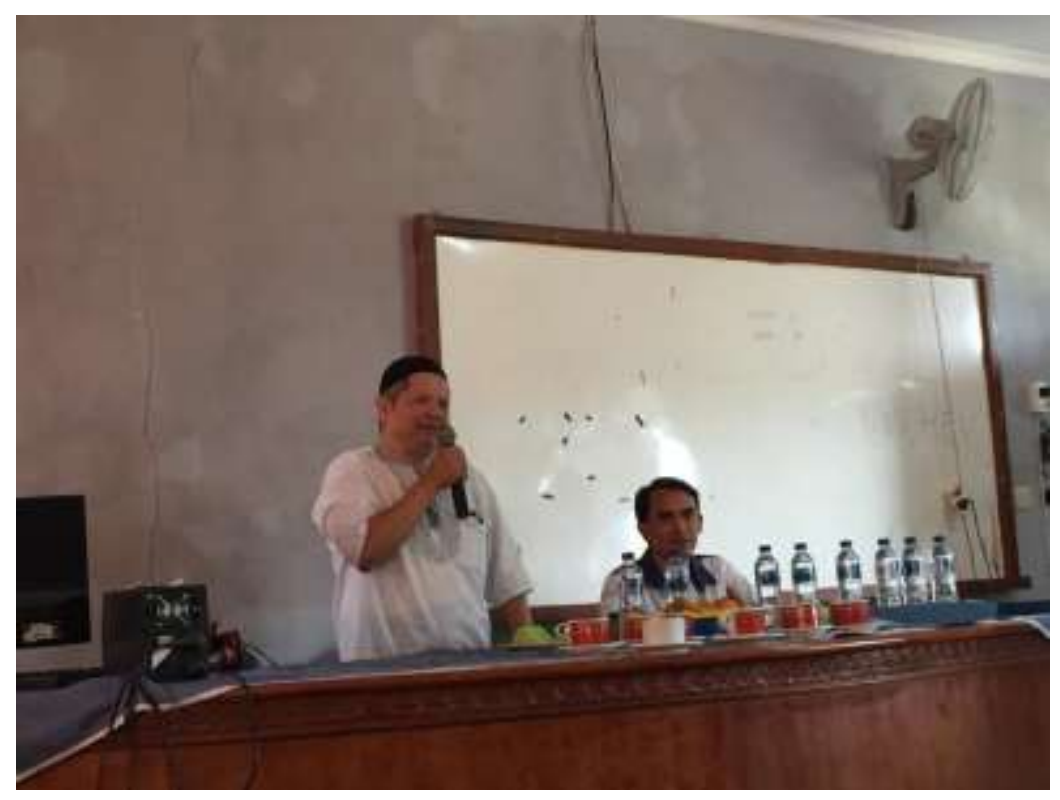

Gambar. 2 Acara pembukaan kegiatan pelatihan e-Learning oleh Wakasek Kurikulum SMAN 1 Jasingan Kabupaten Bogor

Setelah sesi sambutan dari pihak sekolah, sesi selanjutnya adalah pengenalan eLearning secara langsung dibawakan oleh narasumber. Dalam sesi ini semua peserta menimak secara seksama perihal penggunaan sistem operasionalnya. Adapun materi pokok dalam kegiatan ini meliputi Course Management, Lecturer Management, dan Course Participation.

Course Management ini meliputi pengaturan menu yang sajikan untuk pendistribusian matapelajaran pada file-file yang telah disediakan. Lecturer Management terdapat dua bagian utama yaitu menajemen guru dan menajemen mata pelajaran setiap guru. Manajemen guru berfungsi sebagai pengaturan dalam aktivitas pembelajaran input file matapelajaran, pemberian tugas dan pembertahuan lainnya. Course Participation merupakan bentuk menu yang disediakan sebagai tempat dimana setiap guru akan memperoleh informasi untuk matapelajaran yang akan diajarkan dan pada kelas mana saja yang akan diajar. Semua menu tersebut pada dasarnya telah diatur oleh administrator sekolah yang merupakan central pengaturan. Secara berturut-turut visual menumenu tersebut dapat dilihat dalam Gambar.3. 


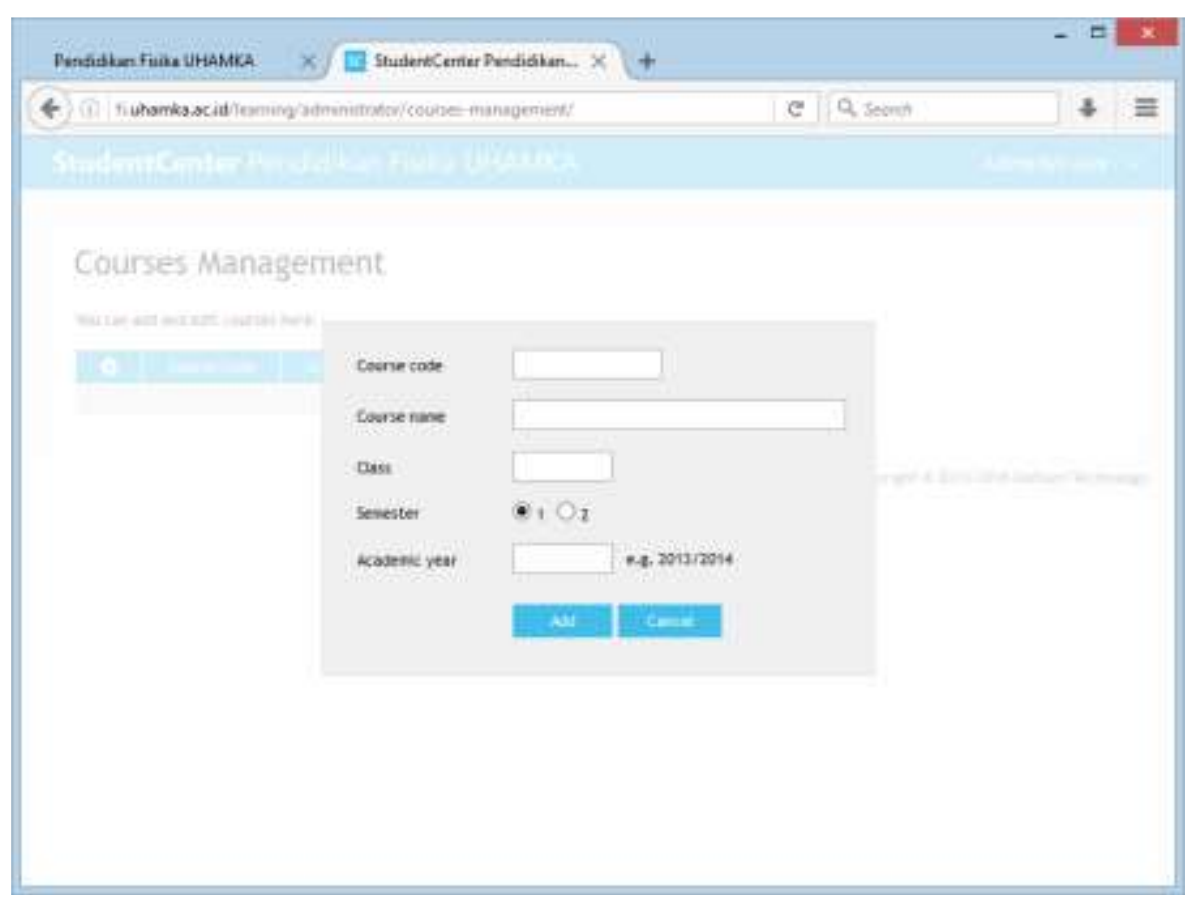

Gambar.3a Tampilan menu Course Management untuk pembelajaran e-Learning

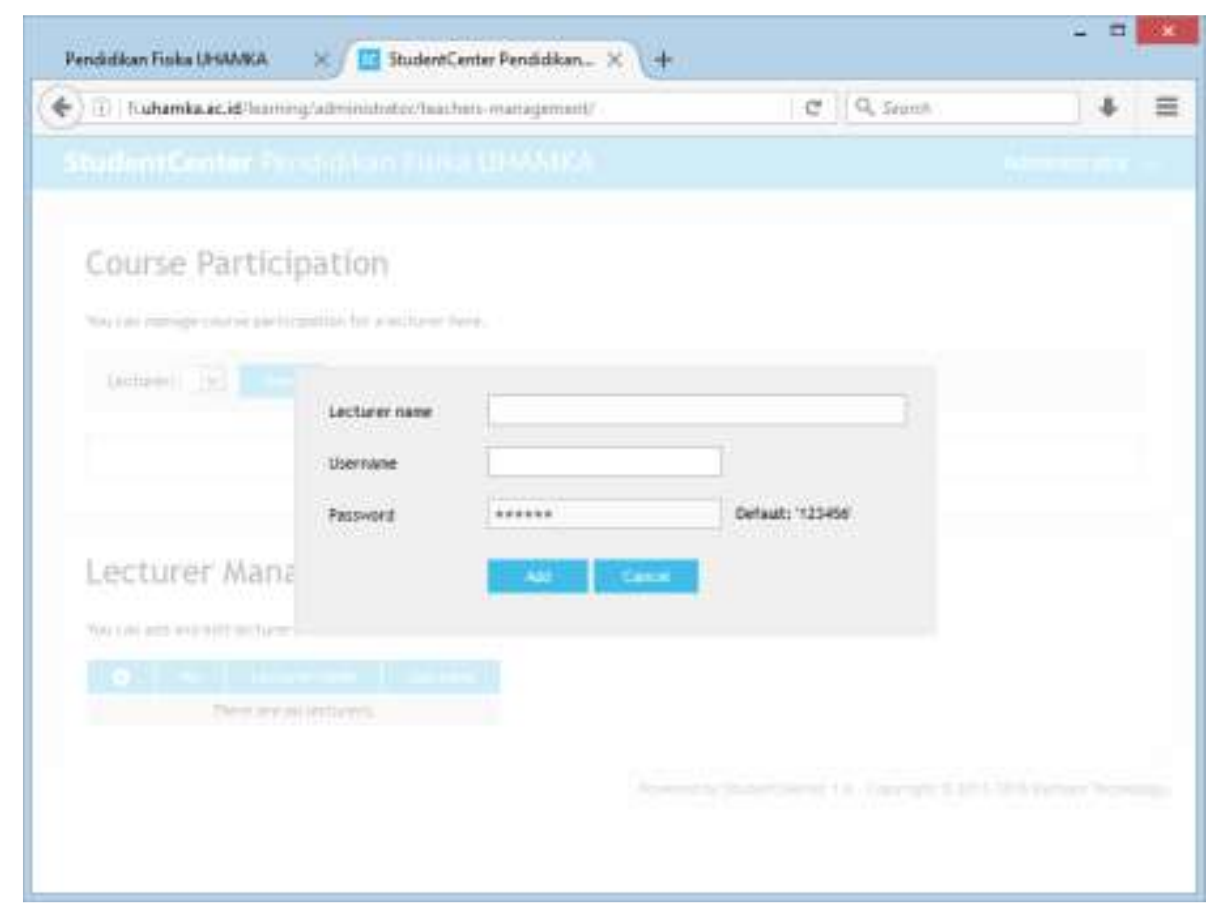

Gambar.3b Tampilan menu Lecture Management untuk pembelajaran e-Learning 


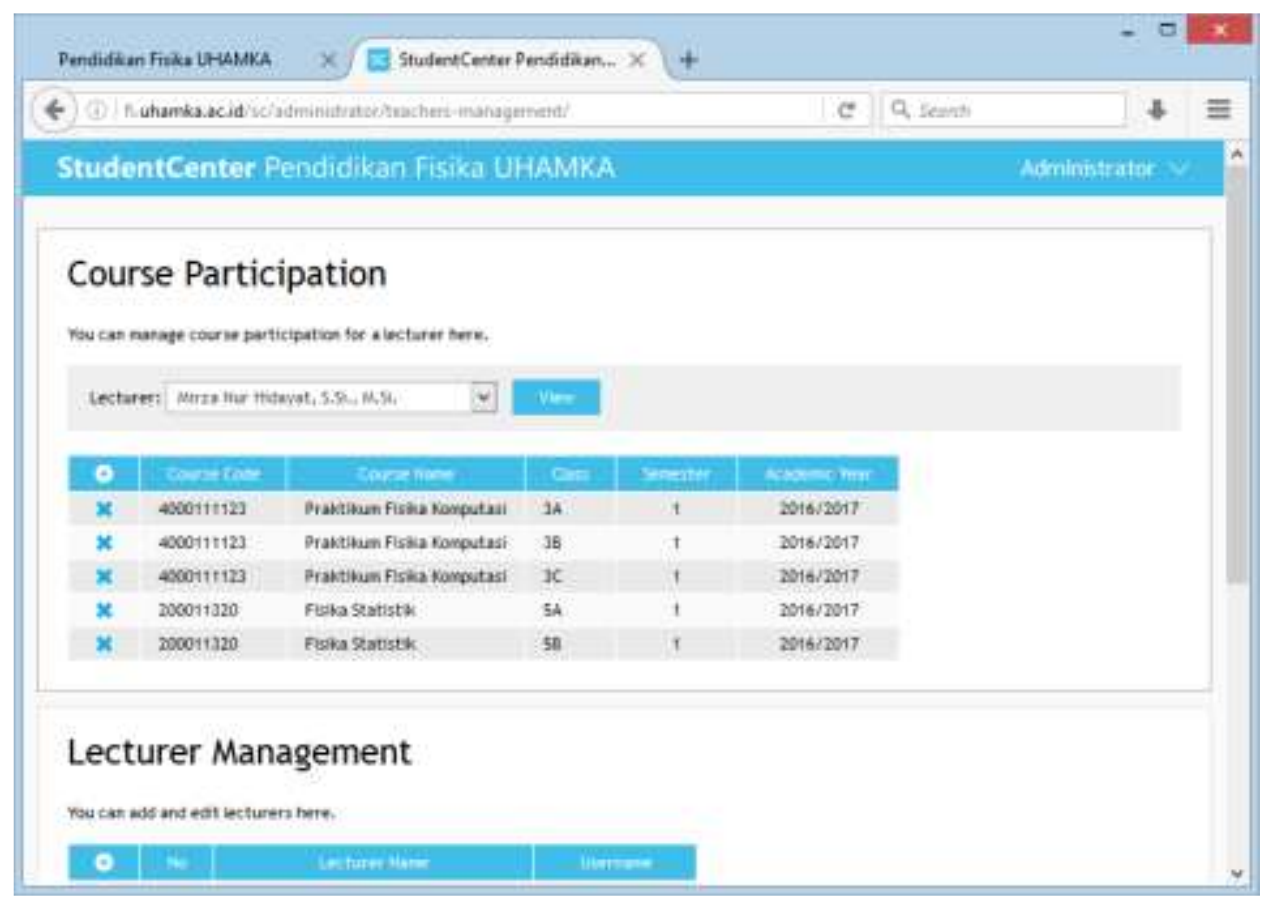

Gambar.3c Tampilan menu Course Participation untuk pembelajaran e-Learning

Perihal penyampain meteri dalam pelatihan manajemen e-learning ini secara khusus dapat dilihat dalam Gambar.4.

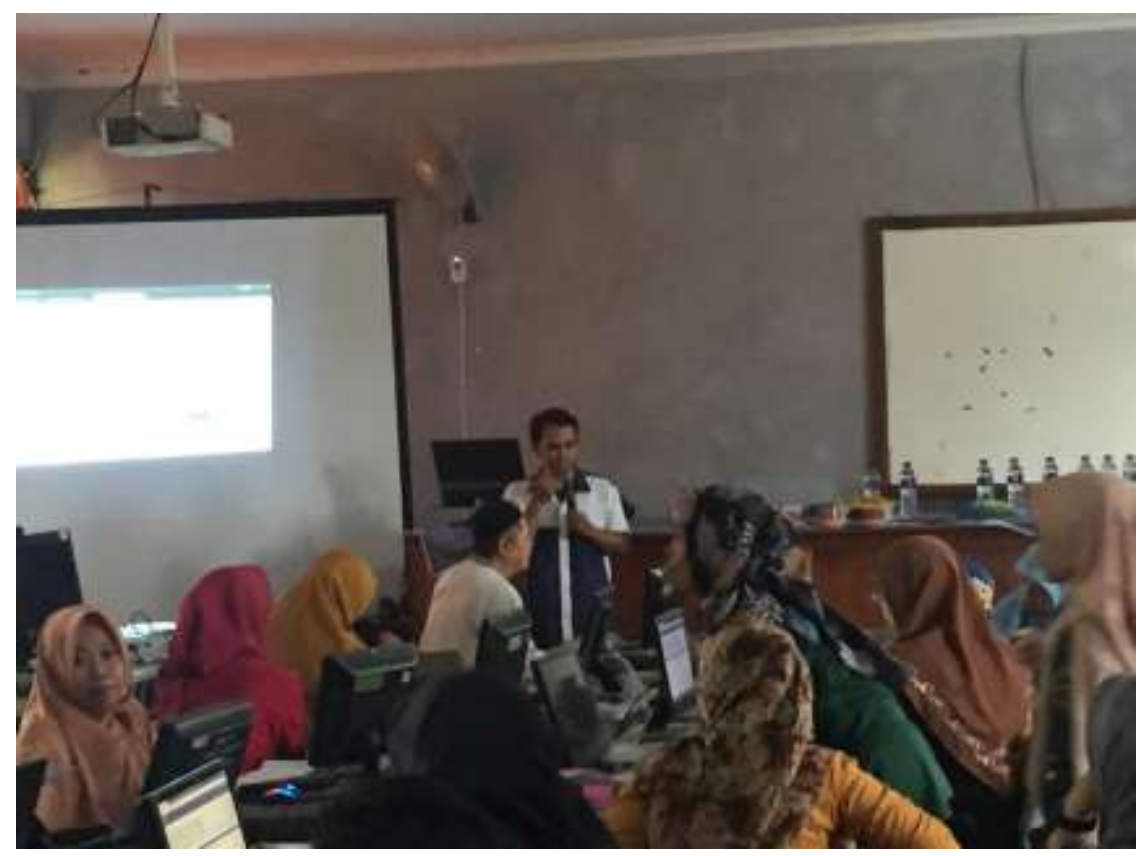

Gambar.4 Penyampaian materi e-Learning di SMAN 1 Jasinga Kabupaten Bogor 
Semua bentuk menu yang disajikan dalam sistem e-learning ini, secara teknis telah memenuhi kebutuhan secara global. Sehingga bentuk tersebut secara mudah dapat diakses secara mobile(Seta, Wati and Mudakurniawan, 2015)

c. Pelatihan manajemen e-Learning

Pelatihan manajemen e-Learning meliputi kegiatan praktik secara langsung oleh guru-guru di SMAN 1 Jasinga dan didampingi oleh dua orang mahasiswa. Dua mahasiswa tersebut mendapingi para guru yang masih mengalami kesulitan dalam pengoperasian e-Learning. Dalam kegiatan Pelatihan manajemen eLearning ini tidak diikuti oleh siswa(i) dikarenakan padatnya kegiatan disekolah dan semua guru yang terlibat dalam prose belajar-mengajar semua terlibat dalam kegiatan pelatihan ini. Ketidak hadiran siswa ini juga telah mendapat intruksi secara langsung bahwa kegiatan ini sebaiknya diikuti oleh para guru dan staf saja. Dan untuk kedepan para guru dan staf yang akan melakukan pengembangan lebih lanjut sehingga dapat meningkatkan kopetensi antara staf, guru dan siswa (Angriani and Dayat, 2019)

Luaran atau hasil akhir yang diharapkan setelah dilaksnakannya kegiatan ini yaitu berupa elaborasi antara pihak sekolah dan Universitas Muhammadiyah Prof. DR. HAMKA berupa penerapan sistem e-Learning untuk pembelajaran khususnya jarak jauh. Tentu saja hal ini diawali dengan MOU terlebih dahulu. Mudah-mudahan kegiatan dapat terjalin secara berkeseinambungan.
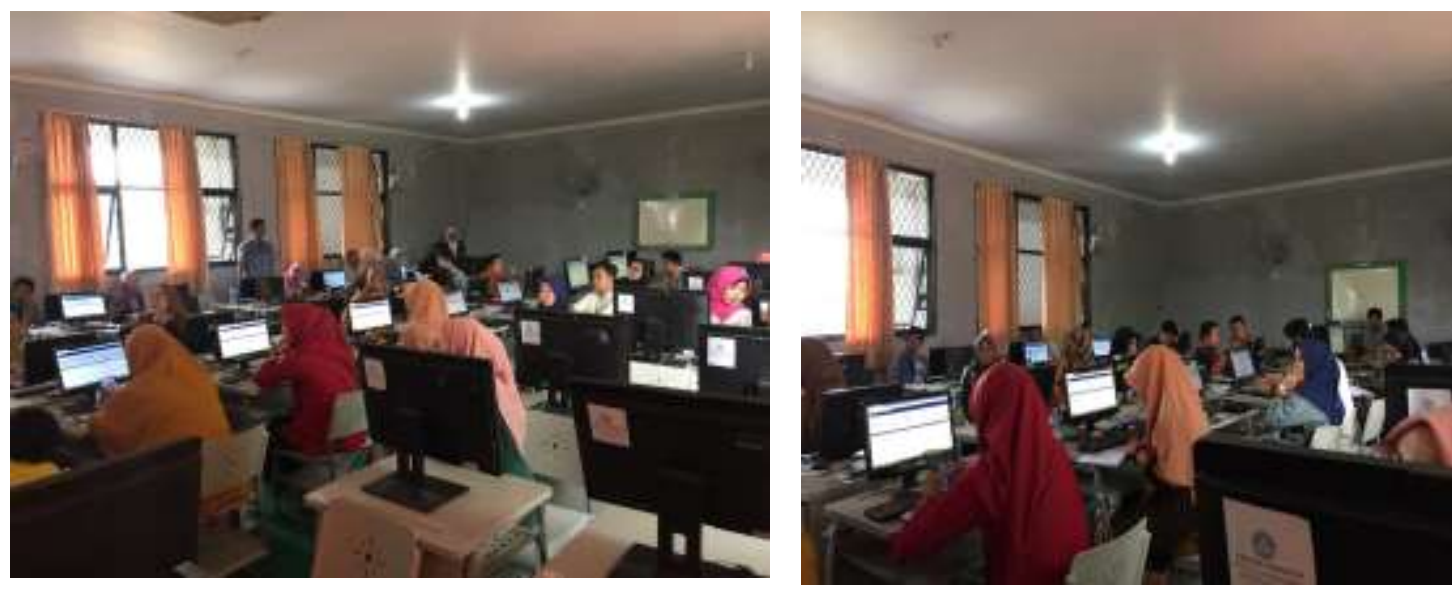

Gambar.4 Kegiatan pelatihan manajemen e-Learning di SMAN 1 Jasinga Kabupaten Bogor

\section{Simpulan dan Rekomendasi}

\section{Simpulan}

Kegiatan pengabdian kepada masyarakat pelatihan manajemen e-Learning di SMAN 1 Jasinga mendapat respon yang baik dari pihak sekolah dan hampir semua guru terlibat dalam kegiatan tersebut. Hanya saja dalam kegiatan ini tidak diikuti oleh para siswa(i) dikarenakan padatnya kegiatan di sekolah, hal juga mendapatkan intruksi secara langsung dari kepala sekolah. 


\section{Rekomendasi}

Sebaiknya kegiatan pengabdian kepada masyarakat ini dilakukan secara kontinu berkeseinambungan sehingga apa yang telah diworkshopkan dipastikan secara benar kiranya program e-Learning yang ditawarkan dapat digunakan sebagai pembelajaran di sekolah, khususnya SMAN 1 Jasinga Kabupaten Bogor.

\section{Acknowledgements}

Terlaksananya kegiatan pengabdian masyarakat e-Learning ini dapat terlaksana melalui kegiatan hibah internal yang diselenggarakan oleh LPPM Universitas Muhammadiyah Prof. DR. HAMKA-Jakarta untuk edisi pertama di tahun 2019.

\section{Daftar Pustaka}

Alenezi, A. (2018) 'Barriers to Participation in Learning Management Systems in Saudi Arabian Universities', Education Research International, 2018. doi: 10.1155/2018/9085914.

Angriani, L. and Dayat, A. R. (2019) 'PKM Peningkatan Kompetensi Guru dan Siswa melalui Pelatihan Pemrograman dan Jaringan Komputer pada Sekolah Menengah Kejuruan di Kota Jayapura', Jurnal Pengabdian kepada Masyarakat, 23(2), pp. 92-98. doi: http://dx.doi.org/10.15294/abdimas.v23i2.16463.

Harandi, S. R. (2015) 'Effects of e-learning on Students' Motivation', Procedia - Social and Behavioral Sciences, 181(May), pp. 423-430. doi: 10.1016/j.sbspro.2015.04.905.

Jati, G. (2013) ‘LEARNING MANAGEMENT SYSTEM (moodle) AND E-LEARNING CONTENT DEVELOPMENT’, Jurnal Sosioteknologi, 12(28), pp. 277-289. doi: 10.5614/sostek.itbj.2013.12.28.3.

Mircea, G. and Associate, P. D. (2018) 'the Future of E-Learning: Designing Tomorrow' S Education', (May 2014).

Omwenga, E. (2017) 'A model for evaluating e-learning systems quality in higher education in developing countries Kennedy Hadullo Technical University of Mombasa, Kenya', International Journal of Education and Development using Information and Communication Technology, 13(2).

Seta, H. B., Wati, T. and Mudakurniawan, I. T. (2015) 'Analisis Dan Perancangan Aplikasi Mobile Learning Berbasis Android', Seminar Nasional Teknologi Informasi dan Multimedia, pp. 1-6.

Angriani L, Dayat AR, Mandiri AU, (2019) PKM Peningkatan Kompetensi Guru dan Siswa Melalui Pelatihan Pemrograman dan Jaringan Komputer pada Sekolah Menengah Kejuruan di Kota Jayapura, ABDIMAS 23 (2) : 92-98

awp@pps-unla. (n.d.). E-LEARNING; Panduan Cara Penggunaan Sistem Informasi ELearning. Bandung: awp@pps-unla.org. 
Elda Balina P, F. (2013). Perencanaan dan Implementasi Aplikasi E-Learning Versi Mobile Berbasis Android. SINGUDA ENSIKOM(AIP Conference Proceedings 1867, 020013 (2017); doi: 10.1063/1.4994416), 76-81.

Jati, G. (2013). LEARNING MANAGEMENT SYSTEM (moodle) AND E-LEARNING CONTENT DEVELOPMENT. Jurnal Sosioteknologi Edisi 28 Tahun 12, 277-28

Petro S, Swatan KH, (2019) Pelatihan Microsoft Excel Sebagai Penunjang Ketrampilan Hard Skill Bagi Siswa Pada SMK YPSEI Palangka Raya, ABDIMAS 2(2) 280-286

Suparman AR, Paiki F F, Pelatihan Penggunaan Media ICT Online bagi Guru, Orang Tua dan Siswa SMP IT Insan Mulia Manokwari berupa Edmodo dan Schoology, ABDIMAS 2(2) 251-261, doi.org/10.15294/abdimas.v23i2.16463 